\title{
大振幅応答を実現する震動台実験手法の構築と超高層建物の室内安全性 DEVELOPMENT OF SHAKING TABLE TEST TECHNIQUES TO REALIZE LARGE RESPONSES AND EVALUATION OF SAFETY OF A HIGH-RISE BUILDING
}

\author{
榎田竜太*1, 長江 拓也*2, 梶原浩一*3, 紀 暁 東*4, 中島 正 愛*5 \\ Ryuta ENOKIDA, Takuya NAGAE, Kouichi KAJIWARA, \\ Xiaodong JI and Masayoshi NAKASHIMA
}

\begin{abstract}
To examine the performance of furniture in the top stories of high-rise buildings particularly under long-period ground motions, a full-scale shaking table test was conducted in E-defense. A mass-and-rubber system was designed to overcome the limitation of the shaking table. A five-story specimen with large stiffness was set on the rubber-and-mass system. It enables that different stories' responses are same and a lot of furniture experiments are carried out simultaneously. The waves generated from the inverse dynamic compensation were taken as inputs. The test results show that the large responses at the top stories can be reproduced reasonably. Through the shaking table test, physical data of furniture in high-rise buildings under long-period ground motions were obtained.
\end{abstract}

Keywords: Long-period ground motion, High-rise building, Floor response, Shaking table test, Furniture キーワード : 長周期地震動, 超高層建物, 床応答, 震動台実験, 家具什器

1. はじめに

海溝型の巨大地震によって長周期地震動が発生し，その地震動を 受ける超高層建物は長時間, 大振幅で摇れる可能性が指摘されてい る 1). 長周期地震動を受けて長時間摇れる超高層建物の室内におい て, 家具什器は居住者に対する凶器と化すことが危惧される. 長周 期地震動による超高層建物の応答を実規模で再現し, こうした室内 の危険性を総合的に検証することは極めて重要な課題である. そこ では, 家具什器のすべりや転倒等の現象を加速度や速度などを用い て工学的見地から評価しつつ, 室内としての総合的な被害軽減対策 を示すことが必要であるが, 同時に, 地震時における超高層建物の 室内状況を忠実に再現した記録映像は防災教育における有力な資料 としての価值をもつ.

2006 年度に長周期地震動による超高層建物の床応答を再現する 震動台実験が行われた ${ }^{2)}$ ，そのなかでは，E-ディフェンス震動台の 制約条件を整理し, 積層ゴム支承を増幅システムとして用いること で，アキュームレータの放出油量を節約する実験システムを提案し ている．超高層建物内の非構造部材・家具什器の応答状況を総合的 に検証するために, 試験体内では事務所および住宅における室内状 況が細部にわたって再現され, 実験により貴重な資料が収集された。
ただし,この実験では,一時的な大振幅床応答が実現されたものの, 実験における制約条件等から，これを長時間にわたって実現するこ とはできず, 床応答の忠実な再現までには至っていない. 架具什器 の地震時挙動を再現するためには, 最大レベル振幅とその繰り返し 回数, 継続時間が重要であり ${ }^{3)}$, 目標応答をできるだけ忠実に再現 する必要がある.

本研究では, 上記の実験で用いられた増幅システムよりも, 更な る大振幅応答を可能にする新たな実験システムを構築する.さらに, 室内の安全性という観点から床応答再現を合理的に達成す心゙く, 複 数の震動台入力波作成手法を与えられた制約条件のなかで比較, 検 討し, 最適な入力波を用いて E-ディフェンス震動台実験を行う。

本論文の構成として，2 章では再現を目標とする応答と E-ディ フェンス震動台の限界について説明する. 3 章では目標応答を再現 するための実験システムについて説明し, 各種の制約条件を整理す る. 4 章において, 制約条件に照らし合わせて目標応答を再現寸る ための震動台への入力波を決定する．6，7章では, 決定された入力 波を用いた E-ディフェンス震動台実験の床応答結果を検証する. 8 章では, 大振幅床応答が再現された試験体内の家具什器の挙動を考 察する.

\footnotetext{
*1 京都大学大学院建築学専攻 修士課程

*2 独立行政法人防災科学技術研究所兵庫耐震工学研究センター 研究員 - 博士 (工学)

*3 独立行政法人防災科学技術研究所兵庫耐震工学研究センター 主任研究員・博士 (工学)

*4 京都大学防災研究所 JSPS 研究員 - 博士 (工学)

*5 京都大学防災研究所 教授 $\cdot \mathrm{Ph}$. D.
}

Graduate Student, Faculty of Eng., Kyoto University

Researcher, EERC, NIED, Dr. Eng.

Senior Researcher, EERC, NIED, Dr. Eng.

JSPS Researcher, DPRI, Kyoto University, Dr. Eng.

Prof., DPRI, Kyoto University, Ph. D. 


\section{2. 超高層応答再現と E-ディフェンス震動台}

\section{1 目標応答と想定 30 階建物の床応答}

震動台実験で再現を目標とする床応答は，兵庫県に建つ超高層建 物を想定した30階建物の最上層床応答である。長周期地震動を受け る想定建物の床応答は，地震応答解析 4) から求められる. 想定建物 は既往の資料を参考に設計し，1次固有周期を 2.8 秒に設定した。解 析には，想定南海地震に基づき兵庫県神戸市の市内沿岸部の東遊園 地に予測される模擬地震動（以降，東遊園地波）を用いる5). 図 1 に 東遊園地波の時刻歴波形を示寸。東遊園地波の最大加速度は2.5 $\mathrm{m} / \mathrm{s}^{2}$ であり，最大速度は $0.7 \mathrm{~m} / \mathrm{s}$ あ゙る。継続時間は 200 秒以上であ り，加速度応答スペクトル $(\mathrm{h}=0.02)$ は図 2 のように 3 秒から 4 秒の 周期において大きな振幅を有する。 NS方向では，想定 30 階建物の 1 次固有周期 (2.8秒) 付近で特に振幅が大きくなっており, $8.5 \mathrm{~m} / \mathrm{s}^{2}$ を 超える.

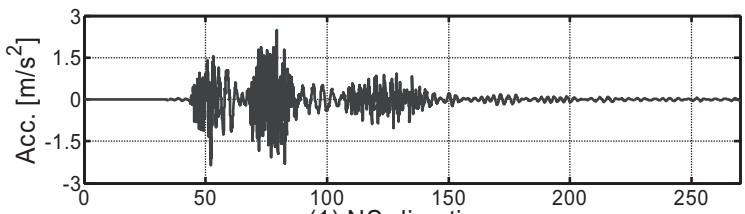

(1) NS-direction

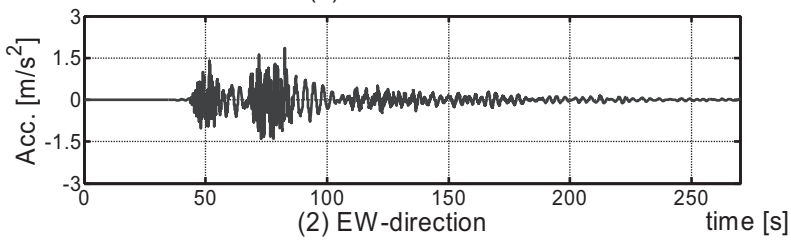

図 1 東遊園地波

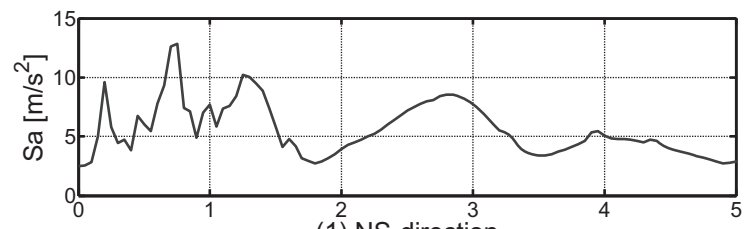

(1) NS-direction

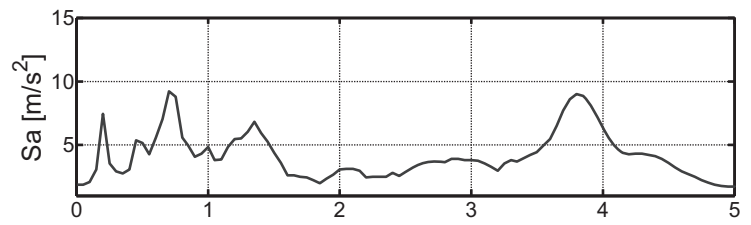

(2) EW-direction period [s]

図 2 東遊園地波の加速度応答スペクトル

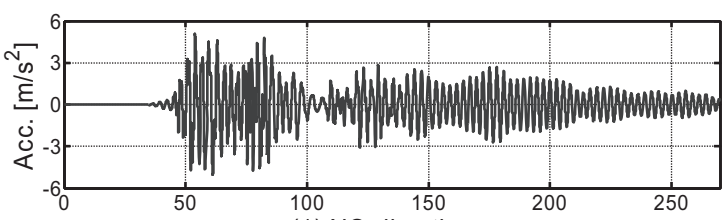

(1) NS-direction

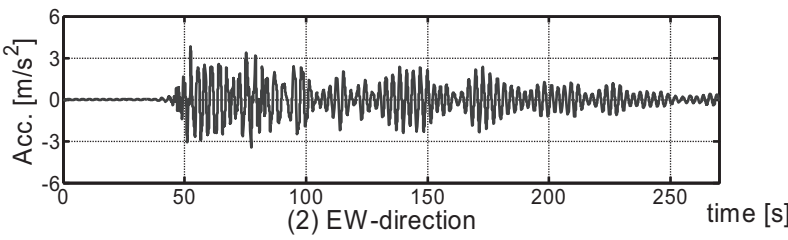

図 3 目標応答加速度波形
解析の結果，想定した30階建物は，3階から10階にかけて最大層 間変形角が0.015 radを超えて弾塑性挙動を示した. 最上階の床応答 変位は50 120秒の間に NS方向 $1.24 \mathrm{~m}, \mathrm{EW}$ 方向 $0.93 \mathrm{~m}$ の最大振幅 に達し, さらに 120 秒以降に約 $0.50 \mathrm{~m}$ の振幅が多数回繰り返された. ここで, 最大振幅を記録する50 120秒の応答を1次イベントと称し， 120 秒以後の応答を 2 次イベントと称す。本実験では，本研究が提案 する増幅システムの限界に挑戦するために目標応答の最大変位を $1.50 \mathrm{~m}$ に設定する。具体的には, NS方向の応答加速度を $C_{\mathrm{NS}}(=1.50$ $\mathrm{m} / 1.24 \mathrm{~m}$ ) 倍し, $\mathrm{EW}$ 方向は $C_{\mathrm{EW}}(=1.0)$ 倍とする (図3).

\subsection{E-ディフェンス震動台の基本仕様}

E-ディフェンス震動台の水平方向の最大加速度，速度，変位は， それぞれ $9.0 \mathrm{~m} / \mathrm{s}^{2}, 2.0 \mathrm{~m} / \mathrm{s}, 1.0 \mathrm{~m}$ である。また，E-ディフェンス震 動台のアクチュエーター放出限界油量は $20 \mathrm{kl}$ である。目標応答の 最大加速度・速度・変位は $5.08 \mathrm{~m} / \mathrm{s}^{2}, 2.60 \mathrm{~m} / \mathrm{s}, 1.50 \mathrm{~m}$ であり, 目 標応答の最大速度・変位は E-ディフェンスの震動台の限界を超えて いる。また，目標応答加速度を震動台で直接出力した場合に必要と なるアキュームレータ放出油量を E-ディフェンスの油量計算 2) に 従って算出すると， $333 \mathrm{kl}$ (限界油量 $20 \mathrm{kl}$ の約 16 倍）に達する. 震動台の制約条件とアクチュエーター放出限界油量から，目標応答 を震動台への直接入力とすることはできない.

\section{3. 実験システムと制約条件 \\ 3.1 試験体の設計}

E-ディフェンス震動台の限界を超える応答を再現するために，本 実験では震動台と 5 層の鋼構造架構 6) である上部構造物の間に増幅 システム (図 4 の斜線部) を組み込む. 増幅システムは, 径 $1.0 \mathrm{~m}$ の 積層ゴム支承 4 基で支える層を 2 段重ねとすることによって，積層 ゴム支承単体の変形性能の 2 倍の変形性能を得る. 5 層の鋼構造架 構はきわめて高い剛性を有しているため，上部構造物を剛体と仮定 することができる（詳細は後述）。

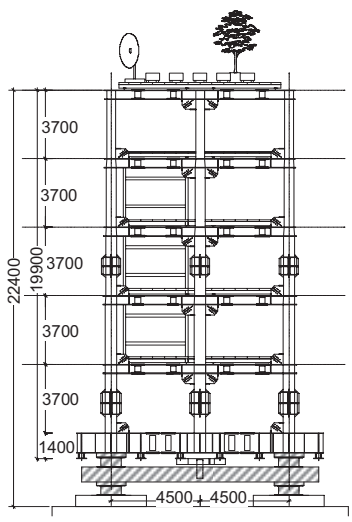

(1) X-direction

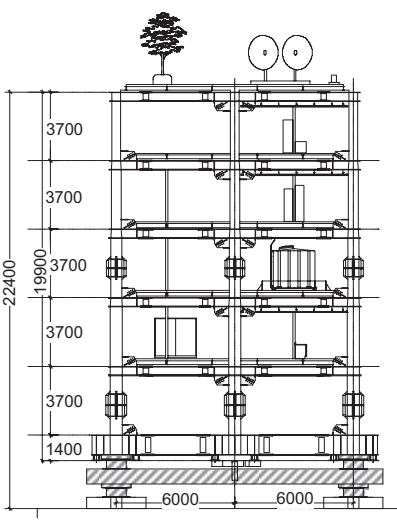

(2) Y-direction
図 4 試験体

コンクリートスラブの質量と積層ゴム支承は以下のように設計し た。まず， 1 層目の質量 $m_{1}$ と 2 層目の質量 $m_{2}$ が等しいと仮定し， 1 層目の剛性 $k_{1}$ を 2 層目の剛性 $k_{2}$ の 1.5 倍とする.これによって, 1 次モードの振動が卓越するときの各層間変位は等しくなる。本研 究では上部構造物が 360 ton と推定されたため, コンクリートスラ 
ブの質量も同様に 360 ton とした．また，増幅システムの各層剛性 の目標值として, 既往の研究 2)を参考に $k_{1}=4.86 \mathrm{kN} / \mathrm{mm} k_{2}=3.24$ $\mathrm{kN} / \mathrm{mm}$ と設定した。 1 層目に $\mathrm{G}_{0} 45$ の天然ゴム（せん断剛性公称值 $G=0.45 \mathrm{~N} / \mathrm{mm}^{2}$ ) を用いた積層ゴム支承 4 基（積層ゴム外形 $\phi=1000$ $\mathrm{mm}$, ゴム総厚 $H=285 \mathrm{~mm}$ ）を, 2 層目に $\mathrm{G}_{0} 30$ の天然ゴム（せん断 剛性公称值 $G=0.3 \mathrm{~N} / \mathrm{mm}^{2}$ ) を用いた積層ゴム支承 4 基（積層ゴム 外形 $\phi=1000 \mathrm{~mm}$, ゴム総厚 $H=285 \mathrm{~mm}$ ) を採用した. 水平剛性 を $K=4 \cdot A \cdot G l H$ によって設定すると, 1 層目の剛性は $4.96 \mathrm{kN} / \mathrm{mm}$ になり， 2 層目の $3.30 \mathrm{kN} / \mathrm{mm}$ になる.

積層ゴム支承の剛性は想定された最大変形 $0.75 \mathrm{~m}$ (ゴムのせん断 変形に等しい)の 0.65 倍の変形時の割線剛性によって代表させる. 上部構造物の質量は吊り上げ時に 395 ton と計測され, 想定された 質量よりも 35 ton 重くなった. 静的実験結果および設計值, 試験体 吊り上げ時測定值に基づく本試験体の諸元を表 1 に示す.

表 1 試験体の質量と剛性

\begin{tabular}{|c|c|c|c|c|c|c|c|}
\hline 層 & 1 & 2 & 3 & 4 & 5 & 6 & 7 \\
\hline 質量 (ton) & 360.0 & 125.0 & 68.2 & 61.4 & 54.6 & 46.8 & 39.0 \\
\hline 剛性 (kN/mm) & 4.8 & 3.1 & 1423.6 & 1042.1 & 842.6 & 650.4 & 521.1 \\
\hline
\end{tabular}

\section{2 試験体のモデル化}

試験体を設計する際に上部構造物を剛体と仮定したが，上部構造 物は 5 層であるため, 試験体は 7 質点系とみなされる。ここでは上 部構造物を剛体として設定できることを確認する，本試験体をせん 断 7 質点モデルとしたときの 1 次固有モード $\boldsymbol{\Phi}_{1}$ を用いて, $\mathrm{i}$ 質点目 と $\mathrm{j}$ 質点目のモード形状差 $M e_{\mathrm{ij}}$ を式(1)のように定義する.このとき， 震動台から i 質点までのモード形状を $\Phi_{1 \mathrm{i}}$ とする.

$$
M e_{\mathrm{ji}}=\frac{\left|\Phi_{1 \mathrm{i}}-\Phi_{1 \mathrm{j}}\right|}{\Phi_{1 \mathrm{j}}} \times 100
$$

式(1)によって得られる 2 質点目と 7 質点目のモード形状差 $M e_{27}$ は僅か $0.35 \%$ \%市，上部構造物は相対的に剛体としてとらえるこ とができる.したがって, 上部構造物の各層（各床面積 $108 \mathrm{~m}^{2}$ ) に ほぼ等しい床応答が再現され，各種の家具什器に関する大規模実験 を同時に実施することができる。また，上部構造物は剛強であるの で, 震動台実験によって上部構造物が損傷を受けることはなく, 多 数回の震動台実験に対応できる.
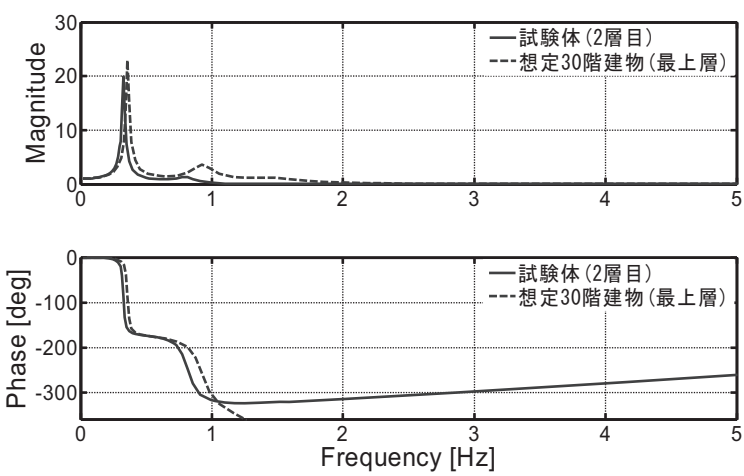

図 5 試験体モデルの伝達関数と想定 30 階建物の伝達関数

上部構造物とコンクリートスラブを剛体と見なし, せん断 2 質点 モデルによって試験体をモデル化する，減衰定数は $3 \%$ \%あると仮
定し, 減衰モデルは剛性比例型とする。モデル化された試験体の伝 達関数と想定 30 階建物の伝達関数を図 5 に示寸. このモデルの 1 次振動数 $f_{1}$ は $0.32 \mathrm{~Hz}$ であり, 想定 30 階建物の 1 次振動数との差 は $0.04 \mathrm{~Hz}$ である.また, モデルの 2 次振動数 $f_{2}$ は $0.81 \mathrm{~Hz}$ である.

\section{3 震動台と試験体に関する制約条件の整理}

目標応答の最大変位と最大速度は震動台の限界を超えているが, 目標応答の最大加速度は震動台の限界を超えていない。目標応答を 再現するための入力加速度は制約条件に対して支配的ではなく，震 動台の制約条件は最大速度と最大变位，およびアキュームレータの 放出限界油量となる.

増幅システムの各層の変形がゴム径 $1.0 \mathrm{~m}$ に接近すると, 積層ゴ ム支承が座屈してしまう恐れがある。そのため，本実験では安全性 を考慮して積層ゴム支承の許容最大変形をゴム径の $75 \%$ に設定す る.また, 積層ゴム支承に過大な引張力を作用させることは望まし くない，本研究では積層ゴム支承に作用する引張力応力度 $\sigma$ を 1 $\mathrm{N} / \mathrm{mm}^{2}$ 以下に抑えるため, 積層ゴム支承の面積と引張応力度から積 層ゴムの最大許容引張力 $N$ を $770 \mathrm{kN}(N=\sigma \cdot A)$ に設定する.

これらの試験体における制約条件とあわせ, 実験システムとして の制約条件は以下のように整理できる.

(1) 震動台の最大速度, 最大変位 $(2.0 \mathrm{~m} / \mathrm{s}, 1.0 \mathrm{~m})$

(2) アキュームレータの放出限界油量 $(20 \mathrm{kl})$

(3) 積層ゴム支承の許容最大変形 $(0.75 \mathrm{~m})$

(4) 積層ゴム支承に作用寸る最大引張力 $(770 \mathrm{kN})$

\section{4 再現された応答の評価と増幅システムの評価}

再現された応答と目標応答に対する評価は, それぞれの応答の最 大值の比較や, 目標応答と再現応答の応答スペクトルの比較などが 用いられる。しかし, 応答の最大值の比較では, 継続時間の長い多 数回の繰り返しを評価できない.また, 応答スペクトルの比較では, 減衰の設定により誤差が変動する，時刻歴波形による評価が最も直 接的であるが，時間のずれが結果に差異を与える。ここでは，波形 の時間のずれに関わる位相にとらわれない周波数成分の振幅を用い, 再現誤差 $E r$ を目標応答・再現応答の加速度フーリエ振幅スペクト ル $S_{\mathrm{tar}} \cdot S_{\mathrm{rep}}$ を用いて式(2)のように定義する.なお, 本評価方法は, 震動台そのものの加振性能評価7)も採用されている.

一方, 震動台によって消費される油量は震動台の累積変位と相関 があり, 震動台の累積変位が大きくになるにつれて消費油量も多く なる。本研究では震動台の累積変位をできるだけ抑えて必要油量を 節約し，所定の大振幅床応答を実現するために増幅システムを導入 した。 その効果を評価するために, 増幅率 $C$ を震動台の累積変位 $T D_{\text {table }}$ と目標応答が再現される層の累積変位 $T D_{\text {target }}$ を用いて式(3) のように定義する。

$$
\begin{gathered}
E r=\frac{\sum\left(S_{\text {rep }}-S_{\text {tar }}\right)^{2}}{\sum S_{\text {tar }}^{2}} \times 100 \\
C=\frac{T D_{\text {target }}}{T D_{\text {table }}} \times 100
\end{gathered}
$$

\section{4. 目標応答再現の検討 \\ 4.1 基準化東遊園地波と応答増幅}

まず，東遊園地波を単純に係数倍した入力波を試験体モデルに入 力することで，提案する試験体の応答特性を検証する. NS 方向の 
目標床応答を $C_{\mathrm{NS}}$ 倍しているので同様に東遊園地波の NS 方向を $C_{\mathrm{NS}}$ 倍し, 基準化遊園地 1 を作成する. 表 2 に示すように基準化東 遊園地波 1 の必要油量は $30 \mathrm{kl}$ であり, 限界油量を超えており, 震 動台への直接入力と寸ることはできない.ここでは試験体の応答特 性を考えるうえで, 必要油量を無視することとし, せん断 2 質点モ デルに対する地震応答解析を行い, その結果を表 3 に示寸.

表 2 制約条件と基準化東遊園地の要求量

\begin{tabular}{|c|c|c|c|c|c|c|c|}
\hline \multirow{2}{*}{ 東遊園地 } & \multicolumn{3}{|c|}{ 振動台の制約条件 } & \multicolumn{4}{|c|}{ 試験体の制約条件 } \\
\cline { 2 - 8 } & 変位 & 速度 & 油量 & \multicolumn{2}{|c|}{ 最大引張力 $(\mathrm{kN})$} & \multicolumn{2}{|c|}{ 最大変形 $(\mathrm{m})$} \\
\cline { 2 - 8 } & $(\mathrm{m})$ & $(\mathrm{m} / \mathrm{s})$ & $(\mathrm{kl})$ & 1層 & 2 層 & 1層 & 2層 \\
\hline 限界 & 1.00 & 2.00 & 20.0 & 770 & 770 & 0.75 & 0.75 \\
\hline 基準化1 & 0.49 & 0.73 & 30.0 & 320 & 780 & 1.07 & 1.13 \\
\hline 基準化2 & 0.39 & 0.58 & 17.0 & -327 & 259 & 0.71 & 0.75 \\
\hline
\end{tabular}

表 3 基準化東遊園地の解析による最大応答値と再現性

\begin{tabular}{|c|c|c|c|c|c|c|c|c|}
\hline \multirow{2}{*}{ 東遊園地 } & \multicolumn{2}{|c|}{ 変位 $(\mathrm{m})$} & \multicolumn{2}{|c|}{ 速度 $(\mathrm{m} / \mathrm{s})$} & \multicolumn{2}{|c|}{ 加速度 $\left(\mathrm{m} / \mathrm{s}^{2}\right)$} & \multicolumn{2}{|c|}{ 再現誤差 $(\%)$} \\
\hline & $\mathrm{X}$ & $\mathrm{Y}$ & $\mathrm{X}$ & $\mathrm{Y}$ & $\mathrm{X}$ & $\mathrm{Y}$ & $\mathrm{X}$ & $\mathrm{Y}$ \\
\hline 目標 & 0.93 & 1.50 & 1.54 & 2.60 & 3.31 & 5.43 & & \\
\hline 基準化1 & 1.05 & 2.38 & 1.87 & 4.43 & 3.60 & 8.53 & 47.71 & 76.43 \\
\hline 基準化2 & 0.83 & 1.55 & 1.48 & 2.89 & 2.84 & 5.57 & 43.93 & 46.31 \\
\hline
\end{tabular}

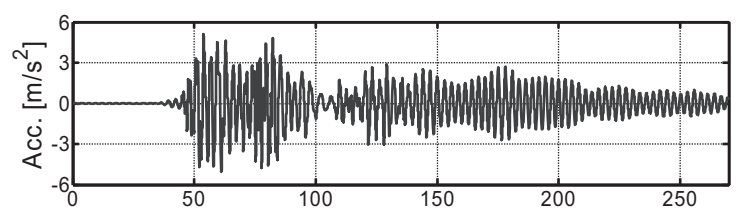

(1)目標応答

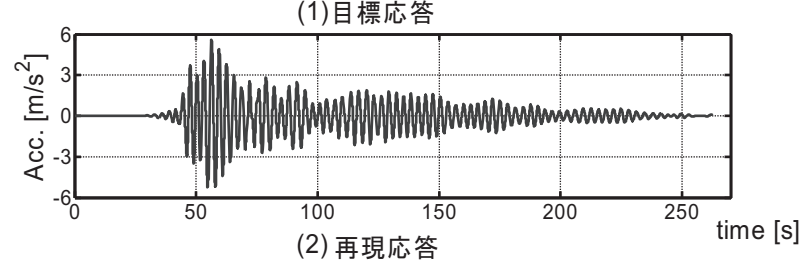

図 6 目標応答と基準化東遊園地波 2 の解析結果 ( $\mathrm{Y}$ 方向)

基準化東遊園地波 1 によって得られた最大床応答加速度 - 速度 変位は $8.54 \mathrm{~m} / \mathrm{s}^{2}, 4.42 \mathrm{~m} / \mathrm{s}, 2.38 \mathrm{~m}$ であり, 目標応答の各最大值の 160\%になっている. ほぼ弾性体の増幅システムに基準化東遊園地 1 をそのまま入力することは, 弾塑性挙動を呈する想定 30 階建物よ りも大きな増幅を与えることを意味している，このとき，基準化東 遊園地 1 による応答值と制約条件を比較すると, 上述した必要油量 に加えて, 積層ゴム支承の変形と引張力が試験体の制約条件を超え ている.

基準化東遊園地波 1 の結果を参考にして, 全積層ゴム支承の許容 最大変形 $(0.75 \mathrm{~m})$ を満たすように 0.79 倍した東遊園地波を基準化 東遊園地 2 として作成する. 新たに作成された基準化東遊園地 2 は すべての制約条件を満足する. 最大基準化東遊園地 2 を用いたせん 断 2 質点モデルの地震応答解析の結果（表 3 ）によると, 得られた 最大床応答加速度・速度・変位は $5.57 \mathrm{~m} / \mathrm{s}^{2}, 2.89 \mathrm{~m} / \mathrm{s}, 1.55 \mathrm{~m}$ であ り, 目標応答の最大值を実現している. ただし, 図 6 に示すように 基準化東遊園地 2 によって再現される応答は 60 秒付近で一時的に 最大応答を生じ, それ以降の振幅は小さくなり, 2 次イベントの振 幅レベルを再現できていない. この結果も想定建物が弾塑性挙動す るのに対して，本試験体がほぼ弾性体であることに由来している.

\section{2 逆解析による補償入力波 $A$}

目標応答と再現応答の再現誤差を小さくするため, 目標応答と試 験体の伝達関数（図 5）から，目標応答を再現するための入力波を 逆解析によって求める.ここでは, IDCS 手法 8), 9) を用いる.

大振幅応答の実現に寄与しない高振動数を試験体の 2 次振動数 $f_{2}$ $(0.86 \mathrm{~Hz})$ 以上の振動数として, ローパスフィルタによってカット して求めた入力波を補償入力波 $\mathrm{A} 1$ (図 7) と称寸. ただし, 油量計算 によると, 補償入力波 $\mathrm{A} 1$ の必要油量 $(37 \mathrm{kl})$ は限界油量を $17 \mathrm{kl}$ 超 えてしまう。ささらに, すべての制約条件を満足するように, 補償入 力波 $\mathrm{A} 1$ にバンドパスフィルター $(0.3 \sim 0.5 \mathrm{~Hz})$ を用いて求めた入力 波を補償入力波 $\mathrm{A} 2$ と称寸. これらの解析結果を比較し, 補償入力 波 $\mathrm{A} 1, \mathrm{~A} 2$ の問題点を考える。

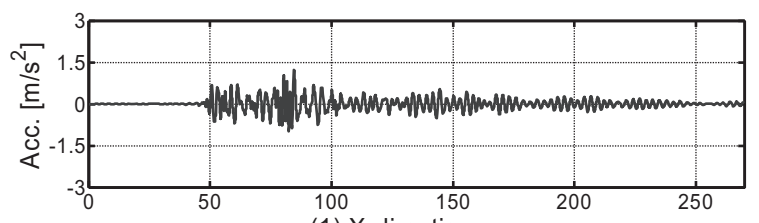

(1) X-direction

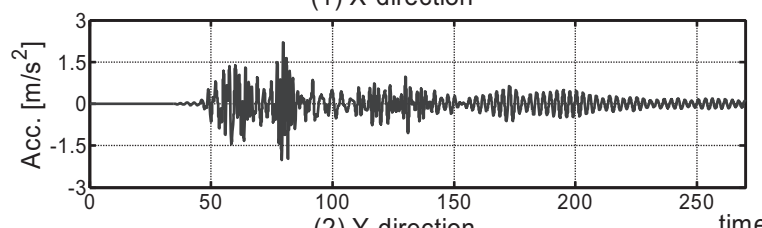

(2) Y-direction time [s]

図 7 補償入力波 $\mathrm{A} 1$

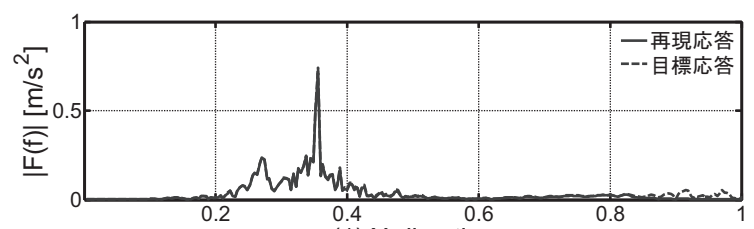

(1) X-direction

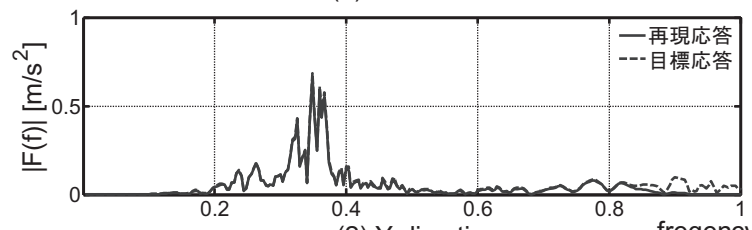

(2) Y-direction

freqency $[\mathrm{Hz}]$

図 8 目標応答と補償入力波 $\mathrm{A} 1$ の解析結果の

フーリエ振幅スペクトル

表 4 制約条件と補償入力波 $\mathrm{A}$ の要求量

\begin{tabular}{|c|c|c|c|c|c|c|c|}
\hline \multirow{2}{*}{ 補償入力 } & \multicolumn{3}{|c|}{ 震動台の制約条件 } & \multicolumn{4}{|c|}{ 試験体の制約条件 } \\
\cline { 2 - 8 } & 変位 & 速度 & 油量 & \multicolumn{2}{|c|}{ 最大引張力 $(\mathrm{kN})$} & \multicolumn{2}{|c|}{ 最大変形 $(\mathrm{m})$} \\
\cline { 2 - 8 } & $(\mathrm{m})$ & $(\mathrm{m} / \mathrm{s})$ & $(\mathrm{kl})$ & 1層 & 2層 & 1層 & 2層 \\
\hline 限界 & 1.00 & 2.00 & 20.0 & 770 & 770 & 0.75 & 0.75 \\
\hline $\mathrm{A} 1$ & 0.70 & 0.41 & 37.0 & -526 & 121 & 0.57 & 0.65 \\
\hline $\mathrm{A} 2$ & 0.17 & 0.40 & 19.0 & -637 & 18 & 0.51 & 0.57 \\
\hline
\end{tabular}

表 5 補償入力波 $\mathrm{A}$ の解析による最大応答值と再現性

\begin{tabular}{|c|c|c|c|c|c|c|c|c|}
\hline \multirow{2}{*}{ 補償入力 } & \multicolumn{2}{|c|}{ 変位 $(\mathrm{m})$} & \multicolumn{2}{c|}{ 速度 $(\mathrm{m} / \mathrm{s})$} & \multicolumn{2}{c|}{ 加速度 $\left(\mathrm{m} / \mathrm{s}^{2}\right)$} & \multicolumn{2}{|c|}{ 現誤差 $(\%)$} \\
\cline { 2 - 9 } & $\mathrm{X}$ & $\mathrm{Y}$ & $\mathrm{X}$ & $\mathrm{Y}$ & $\mathrm{X}$ & $\mathrm{Y}$ & $\mathrm{X}$ & $\mathrm{Y}$ \\
\hline 目標 & 0.93 & 1.50 & 1.54 & 2.60 & 3.31 & 5.43 & & \\
\hline $\mathrm{A} 1$ & 0.85 & 1.47 & 1.48 & 2.17 & 2.83 & 4.76 & 3.55 & 6.23 \\
\hline $\mathrm{A} 2$ & 0.52 & 0.83 & 1.13 & 1.78 & 2.52 & 3.87 & 21.35 & 16.79 \\
\hline
\end{tabular}


補償入力波 $\mathrm{A} 1$ を用いてせん断 2 質点モデルの地震応答解析を行 うと, 図 8 のような結果が得られる。補償入力波 $\mathrm{A} 1, \mathrm{~A} 2$ と制約条 件との関係とその入力による応答の再現誤差を表 4 と表 5 に記寸.

補償入力波 $\mathrm{A} 1$ では再現誤差 $6 \%$ で目標応答を比較的忠実に再現 できている. 補償入力波 $\mathrm{A} 1$ による震動台の累積変位は $43.3 \mathrm{~m}$ であ り, 2 層床の累積変位は $192.7 \mathrm{~m}$ である. 式(3)を用いて増幅システ ムを評価すると, その増幅率 $C_{\mathrm{A}}$ は $445 \%$ となる. 増幅システムに よって入力は $445 \%$ も増幅されるが，補償入力波 $\mathrm{A} 1$ の必要油量は 限界油量を超えてしまう。目標応答には元々の入力地震動である東 遊園地波がもつ 3 秒を超える長周期成分（図 8）が含まれている. 表 4 によれば, 補償入力波 $\mathrm{A} 1$ による積層ゴム支承の各層の最大変 形 (1 層: $0.57 \mathrm{~m}, 2$ 層: $0.65 \mathrm{~m}$ ) は, 積層ゴム支承の許容最大変形に 達していない。これは積層ゴム支承がさらに 0.10 0.15 m の変形を する余裕をもっていることを意味し, 補償入力波 $\mathrm{A} 1$ では増幅シス テムの能力を最大限に活かしきれていない. フィルターによって上 述の長周期成分をカットして作成したのが補償入力波 $\mathrm{A} 2$ であるが, この補償入力波 $\mathrm{A} 2$ は寸べての制約条件を満足するものの, 最大振 幅は目標最大変位・最大加速度の半分程度にしか達しない。

\section{5. 人工目標応答と補償入力波 B1 \\ 5.1 人工目標応答の作成}

目標振幅の実現と必要油量を限界油量以内に収めるという課題を 克服するために, 震動台自身の累積変位をできるだけ抑え, 積層ゴ 厶支承の変形を最大限に利用寸る必要がある，例えば，入力波を試 験体の 1 次振動数を持つ正弦波と寸れば, 試験体が効率的に共振し, 積層ゴム支承の変形能力を最大限に利用でき, 必要油量を合理的に 節約できる。しかし，単純な正弦波では目標応答の 1 次イベントや 2 次イベント等の波形の骨格が持つ起伏を再現することはできない， ここでは, 本試験体に対してより効率的な目標応答として, 元々の 目標応答の骨格曲線を拘束条件とした人工目標応答を作成する。具 体的には, 試験体の 1 次振動数 $f_{1}$ と同じ振動数を持った正弦波を, 骨格曲線に従うように時刻歴で係数倍する。人工目標応答 $T_{\mathrm{art}}(\mathrm{t})$ は 上部骨格曲線 $S_{1}(\mathrm{t})$ と下部骨格曲線 $S_{2}(\mathrm{t})$ を用いると式(4)によって表 され, 図 9 のようになる。人工目標応答の最大加速度・速度 ・ 変位 は $5.43 \mathrm{~m} / \mathrm{s}^{2}, 2.69 \mathrm{~m} / \mathrm{s}, 1.50 \mathrm{~m}$ である.

$$
T_{\text {art }}(t)= \begin{cases}S_{1}(t) \sin \left(2 \pi f_{1} t\right) & \sin \left(2 \pi f_{1} t\right) \geq 0 \\ S_{2}(t) \sin \left(2 \pi f_{1} t\right) & \sin \left(2 \pi f_{1} t\right)<0\end{cases}
$$
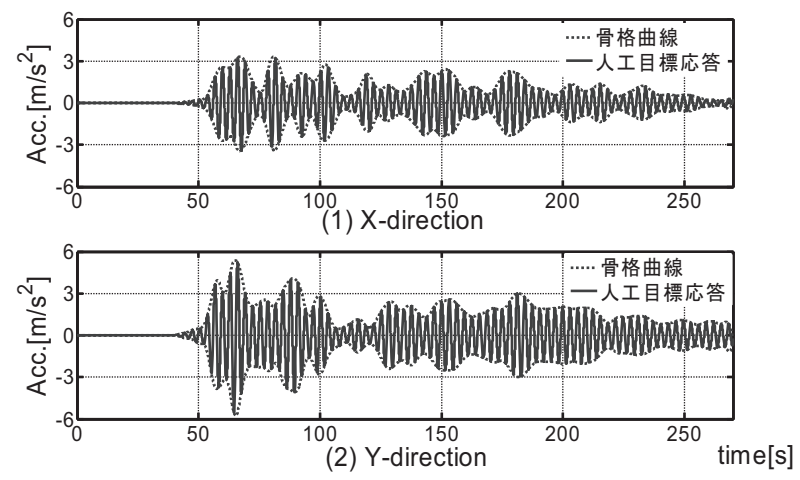

図 9 人工目標応答

\section{2 補償入力波 B1 と解析による再現応答}

人工目標応答に IDCS 手法を用いて入力波形を作成すると，補償 入力波 B1（図 10）が得られる. 補償入力波 B1 を用いてせん断 2 質点モデルの地震応答解析を行うと, 図 11 のような結果が得られ る. 補償入力波 $\mathrm{B} 1$ と制約条件との関係とその入力による応答の再 現誤差を表 6 と表 7 に記す.

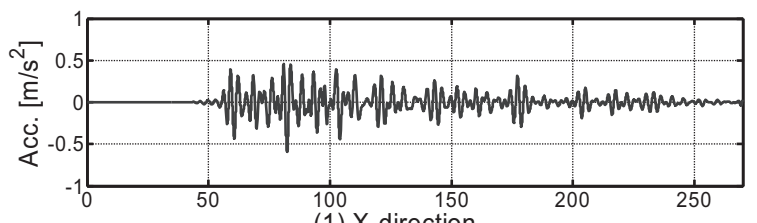

(1) X-direction

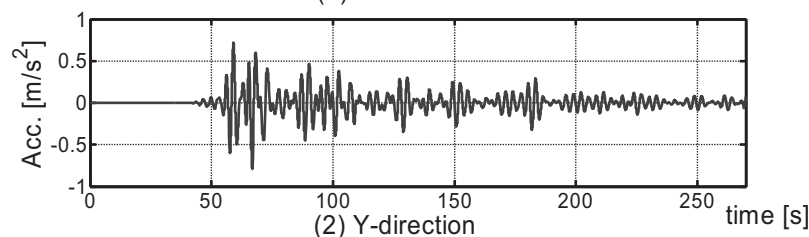

図 10 補償入力波 $\mathrm{B} 1$
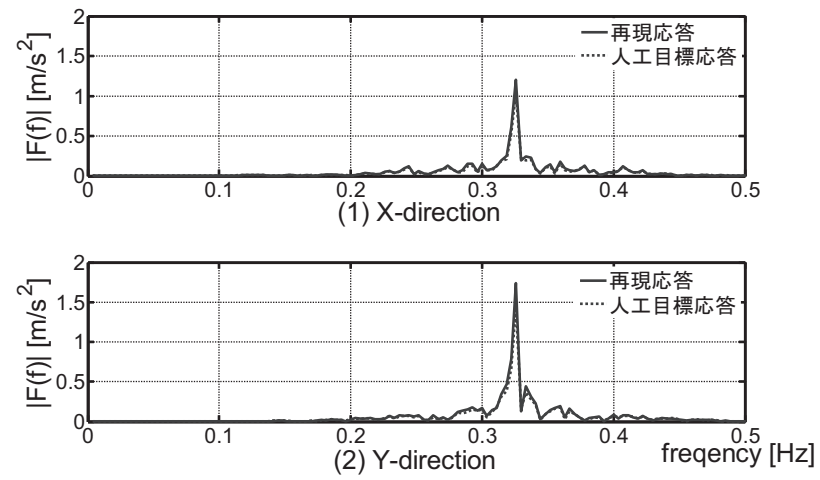

図 11 人工目標応答と補償入力波 $\mathrm{B} 1$ の解析結果の

フーリエ振幅スペクトル

表 6 制約条件と補償入力波 $\mathrm{B} 1$ の要求量

\begin{tabular}{|c|c|c|c|c|c|c|c|}
\hline \multirow{2}{*}{ 補償入力 } & \multicolumn{3}{|c|}{ 震動台の制約条件 } & \multicolumn{3}{|c|}{ 試験体の制約条件 } \\
\cline { 2 - 8 } & 変位 & 速度 & 油量 & \multicolumn{2}{|c|}{ 最大引張力 $(\mathrm{kN})$} & \multicolumn{2}{|c|}{ 最大変形 $(\mathrm{m})$} \\
\cline { 2 - 8 } & $(\mathrm{m})$ & $(\mathrm{m} / \mathrm{s})$ & $(\mathrm{kl})$ & 1層 & 2層 & 1層 & 2層 \\
\hline 限界 & 1.00 & 2.00 & 20.0 & 770 & 770 & 0.75 & 0.75 \\
\hline $\mathrm{B} 1$ & 0.23 & 0.35 & 10.5 & -259 & 315 & 0.71 & 0.75 \\
\hline
\end{tabular}

表 7 補償入力波 $\mathrm{B} 1$ の解析による最大応答值と再現性

\begin{tabular}{|c|c|c|c|c|c|c|c|c|}
\hline \multirow{2}{*}{ 補償入力 } & \multicolumn{2}{|c|}{ 変位 $(\mathrm{m})$} & \multicolumn{2}{c|}{ 速度 $(\mathrm{m} / \mathrm{s})$} & \multicolumn{2}{|c|}{ 加速度 $\left(\mathrm{m} / \mathrm{s}^{2}\right)$} & \multicolumn{2}{|c|}{ 再現誤差 $(\%)$} \\
\cline { 2 - 9 } & $\mathrm{X}$ & $\mathrm{Y}$ & $\mathrm{X}$ & $\mathrm{Y}$ & $\mathrm{X}$ & $\mathrm{Y}$ & $\mathrm{X}$ & $\mathrm{Y}$ \\
\hline 目標 & 0.93 & 1.50 & 1.54 & 2.60 & 3.31 & 5.43 & & \\
\hline $\mathrm{B} 1$ & 0.88 & 1.41 & 1.62 & 2.66 & 3.19 & 5.20 & 0.01 & 0.14 \\
\hline
\end{tabular}

表 6 では，補償入力波 $\mathrm{B} 1$ による積層ゴム支承の各層の最大変形 （1 層で $0.71 \mathrm{~m} ， 2$ 層で $075 \mathrm{~m}$ ) になり，積層ゴム支承の変形能力を 最大限に利用している。 その結果, 入力補償波 B1 による震動台の 累積変位は $23.3 \mathrm{~m}$ になり, 補償入力波 $\mathrm{A} 1$ による震動台の累積変位 $(43.3 \mathrm{~m})$ より $20 \mathrm{~m}$ 少ない值を得ている。これによって, 補償入力 波 B1のアキュームレータ放出油量は $10.5 \mathrm{kl}$ となり, 限界油量 $20 \mathrm{kl}$ の半分程度に抑えられる. 補償入力波 $\mathrm{A} 1$ の結果と比べれば $1 / 4$ 程 度で，増幅システムの効率を格段に高めている。補償入力波 B1 は 
すべての制約条件を満足し，表 7 によれば，新たに設定した人工目 標応答に対する再現誤差は約 $0.1 \%$ となっている. 以上より, 補償 入力波 $\mathrm{B} 1$ を基本に実験を実施することとした.

\section{6. 予備加振実験による入力波の調整}

6.1 システム同定による試験体特性

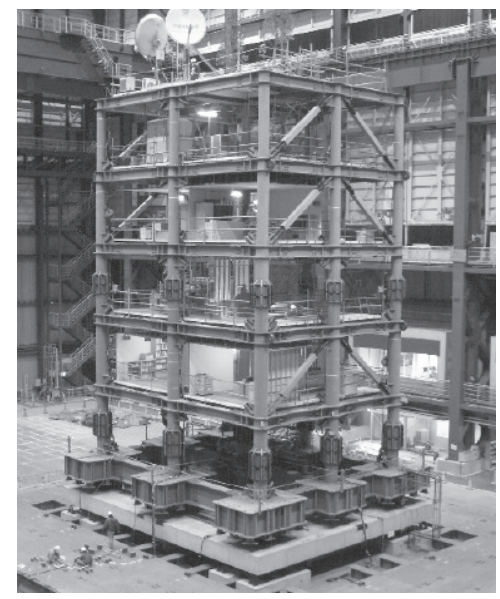

図 12 試験体の全景

試験体の全景を図 12 に示す. 試験体特性を把握するために大振 幅の自由振動実験を実施した。一連の予備実験では, 家具什器の損 壊・損傷を防ぐために, 本加振実験の前の家具什器を周辺架構に十 分に固定した，試験体を効率的に応答させることを目的とし，解析 モデルの 1 次振動数 $f_{1}=0.32 \mathrm{~Hz}$ を参照し, 震動台への入力波として は振動数 $0.30 \mathrm{~Hz}$ の 1 周期正弦波を採用した. 1 周期正弦波の加速 度振幅を $1.5 \mathrm{~m} / \mathrm{s}^{2}$ としたときの, 試験体の 2 層床応答は図 13 とな り, 積層ゴム支承の最大変形は $0.6 \mathrm{~m}$ に達した。 システム同定によ る試験体の特性は表 8 のようになる.

表 8 試験体の特性

\begin{tabular}{|c|c|c|c|c|}
\hline 入力振幅 & \multicolumn{2}{|c|}{ 積層ゴム最大変形 (m) } & 振動数 $(\mathrm{Hz}$ & 減衰 (\%) \\
\hline$\left(\mathrm{m} / \mathrm{s}^{2}\right)$ & 1層 & 2層 & 1次 & 1次 \\
\hline 1.00 & 0.39 & 0.36 & 0.33 & 2.87 \\
\hline 1.50 & 0.60 & 0.57 & 0.32 & 3.10 \\
\hline
\end{tabular}
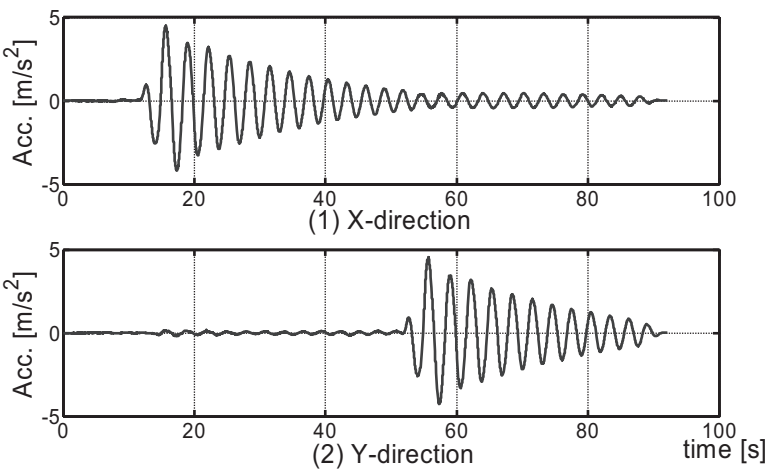

図 131 周期正弦波入力による 2 層床応答加速度

入力加速度振幅 $1.5 \mathrm{~m} / \mathrm{s}^{2}$ の場合において, 試験体の第 1 次振動数 は約 $0.32 \mathrm{~Hz}$, 減衰定数は約 $3 \%$ となり, 減衰定数は試験体をモデ
ル化した際の值にほぼ一致した。このときの積層ゴム支承の層せん 断力と変形の履歴を, 本研究において設定した弾性モデル剛性とと もに図 14 に示す. 1 次モードが卓越する自由振動における，1層と 2 層の積層ゴム支承の最大変形はほぼ等しく, 試験体の 2 層床応答 加速度と屋上の応答加速度の誤差は, 式(2)から $0.06 \%$ で, 2 層床と 屋上ではほぼ同じ応答が再現されている．解析で設定した剛性は 1 層目 $4.80 \mathrm{kN} / \mathrm{mm} ， 2$ 層目 $3.14 \mathrm{kN} / \mathrm{mm}$ である. 本加振の結果にお いて得られた各変形レベルにおける割線剛性の平均值を参照すれば, 1 層目が $4.48 \mathrm{kN} / \mathrm{mm} ， 2$ 層目が $3.26 \mathrm{kN} / \mathrm{mm}$ であり, 設定剛性の 0.93 倍（1 層目）と 1.03 倍（2 層目）である。このように，試験体 は設計時に意図した性能を有し，同定された諸量も解析モデルにお いて想定した諸量にほぼ等しい.
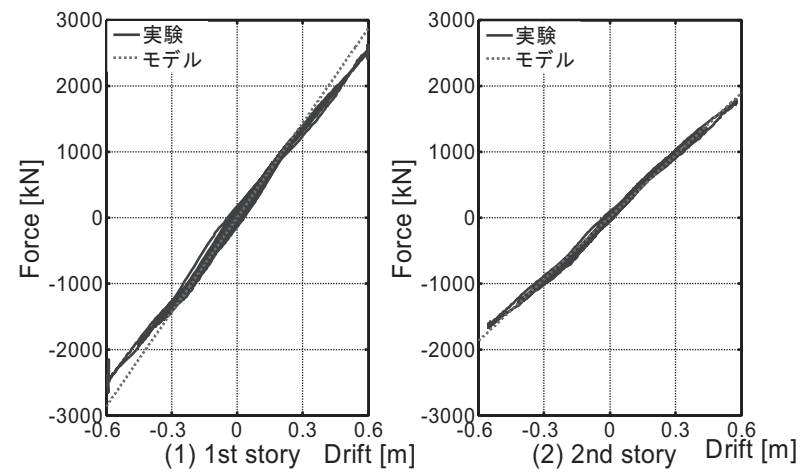

図 141 周期正弦波入力による積層ゴム支承の履歴

\section{2 補償入力波 B1 の実験結果}

事前に補償入力波 $\mathrm{B} 1$ を震動台に入力し, 所定の大振幅応答が再 現されるかを確認した。補償入力波 $\mathrm{B} 1$ を用いた実験によって再現 された応答と人工目標応答を図 15 , 図 16 に示寸，表 9 に人工目標 応答と再現された応答の再現性を示す．補償入力波 $\mathrm{B} 1$ によって再 現された応答の 1 次イベントでは人工目標応答の 0.8 倍であり, 2 次イベントでは人工目標応答の 0.7 倍となった。すなわち, 人工目 標応答を単純に逆解析した補償入力波 B1によって再現された応答 は人工目標応答に達さなかった。本研究では積層ゴム支承を弾性と 仮定して解析用のモデルを設定したが，図 14 を参照すれば，実際 の積層ゴム支承の剛性は, 変形が $0.2 \mathrm{~m}$ 以上になると低下寸るなど の非線形性を示している．解析モデルを設定する際に無視した剛性 変化等の影響が，目標応答実現に至らなかった主な原因である。

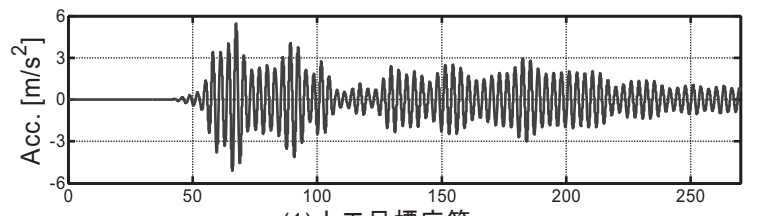

(1)人工目標応答

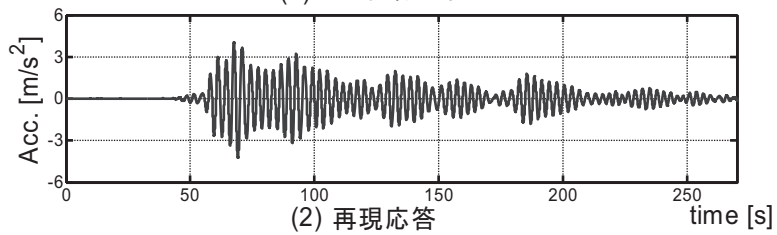

図 15 人工目標応答と補償入力波 $\mathrm{B} 1$ による実験結果（Y 方向） 


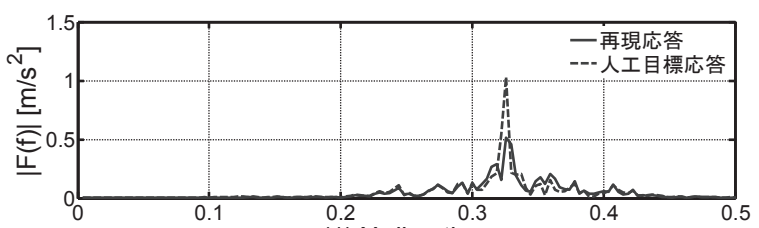

(1) X-direction

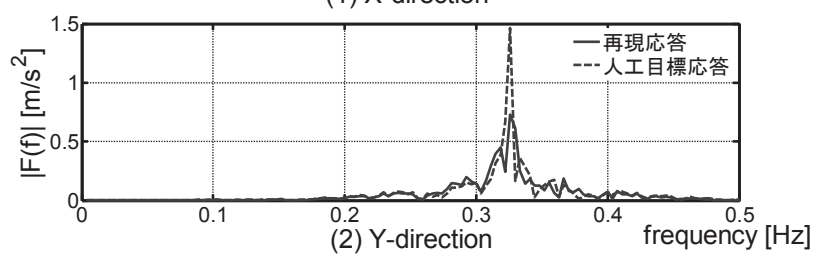

図 16 人工目標応答と補償入力波 $\mathrm{B} 1$ による応答の

$$
\text { フーリエ振幅スペクトル }
$$

表 9 補償入力波 $\mathrm{B} 1$ による最大応答値と再現性

\begin{tabular}{|c|c|c|c|c|c|c|c|c|}
\hline \multirow{2}{*}{$B 1$} & \multicolumn{2}{|c|}{ 変位 $(\mathrm{m})$} & \multicolumn{2}{c|}{ 速度 $(\mathrm{m} / \mathrm{s})$} & \multicolumn{2}{c|}{ 加速度 $\left(\mathrm{m} / \mathrm{s}^{2}\right)$} & \multicolumn{2}{|c|}{ 現誤差 $(\%)$} \\
\cline { 2 - 9 } & $\mathrm{X}$ & $\mathrm{Y}$ & $\mathrm{X}$ & $\mathrm{Y}$ & $\mathrm{X}$ & $\mathrm{Y}$ & $\mathrm{X}$ & $\mathrm{Y}$ \\
\hline 目標 & 0.93 & 1.50 & 1.54 & 2.60 & 3.31 & 5.43 & & \\
\hline 実験結果 & 0.71 & 1.24 & 1.37 & 2.18 & 2.82 & 4.22 & 28.97 & 29.51 \\
\hline
\end{tabular}

\section{7. 本加振実験における補償入力波 B2 の結果}

家具什器の地震時挙動は最大振幅レベルとその繰り返し回数に大 きな影響を受ける。そこで, 補償入力波 $\mathrm{B} 1$ による予備実験結果を 反映して 1 次イベント, 2 次イベント別に入力振幅を調整した補償 入力波 $\mathrm{B} 2$ を作成する. 予備解析による検討を踏まえ, 1 次イベン 卜では積層ゴム支承の変形が許容最大変形 $(0.75 \mathrm{~m})$ を超えないよう に 1/0.8(=1.25) よりも小さい 1.1 を乗じ, 2 次イベント部分におい ては 1/0.7（=1.4）をそのまま乗じることで入力波を作成し，本実験 に採用した。このとき,アキキュームレータ放出油量は $14.5 \mathrm{kl}$ であ り，制約条件を十分に下回っている.

本実験において, 補償入力波 $\mathrm{B} 2$ を試験体に入力して得られた応 答と目標応答を図 17 と図 18 に示寸. また, 表 10 に目標応答と再 現された応答の再現性を示す。本実験による震動台の累積変位は $24.5 \mathrm{~m}$ であり，2 層床の累積変位は $214.7 \mathrm{~m}$ であった. 式(3)を用 いると, 本研究の提案する増幅システムの増幅率 $C_{\mathrm{B}}$ は $876 \%$ であ り, これは補償入力波 $\mathrm{A} 1$ における $C_{\mathrm{A}}$ の約 2 倍に達している. この 際に, 1 層目の積層ゴム支承の最大変形は $0.75 \mathrm{~m}$ であり, 2 層目の 積層ゴム支承の最大変形は $0.70 \mathrm{~m}$ である.

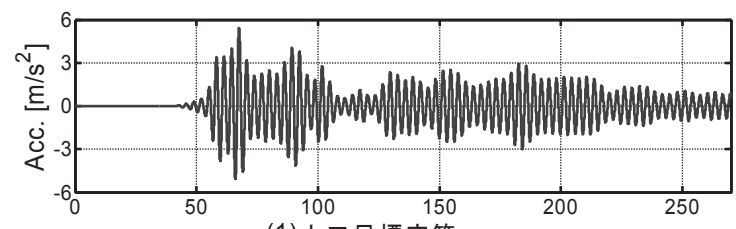

(1) 人工目標応答

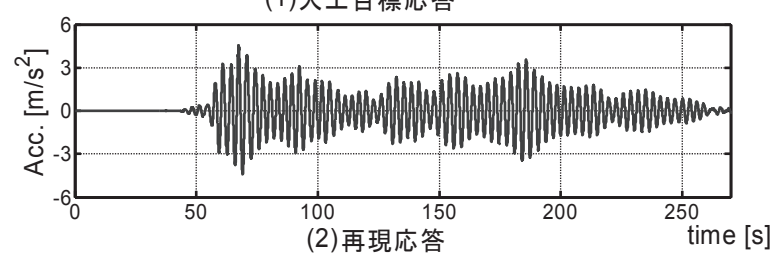

図 17 人工目標応答と補償入力波 $\mathrm{B} 2$ による実験結果（Y 方向）

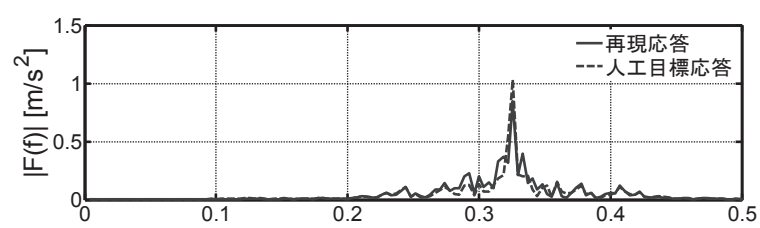

(1) X-direction

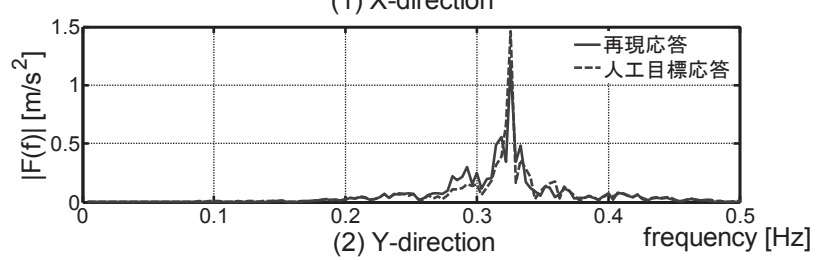

図 18 人工目標応答と補償入力波 $\mathrm{B} 2$ による応答の

$$
\text { フーリエ振幅スペクトル }
$$

表 10 補償入力波 $\mathrm{B} 2$ による最大応答值と再現性

\begin{tabular}{|c|c|c|c|c|c|c|c|c|}
\hline \multirow{2}{*}{ B2 } & \multicolumn{2}{|c|}{ 変位 $(\mathrm{m})$} & \multicolumn{2}{c|}{ 速度 $(\mathrm{m} / \mathrm{s})$} & \multicolumn{2}{c|}{ 加速度 $\left(\mathrm{m} / \mathrm{s}^{2}\right)$} & \multicolumn{2}{|c|}{ 再現誤差 $(\%)$} \\
\cline { 2 - 9 } & $\mathrm{X}$ & $\mathrm{Y}$ & $\mathrm{X}$ & $\mathrm{Y}$ & $\mathrm{X}$ & $\mathrm{Y}$ & $\mathrm{X}$ & $\mathrm{Y}$ \\
\hline 目標 & 0.93 & 1.50 & 1.54 & 2.60 & 3.31 & 5.43 & & \\
\hline 実験結果 & 0.79 & 1.33 & 1.44 & 2.26 & 3.02 & 4.56 & 19.61 & 13.79 \\
\hline
\end{tabular}

\section{8. 家具什器の実規模実験}

以降では，本実験において大振幅で長時間の床応答を与えられた 室内の家具什器の挙動に着目し, 室内安全性を考察する.

\section{1 家具什器の配置}

試験体の各階には各種の室内を忠実に再現した。2 階にはオフィ スを模擬した 2 部屋を用意した。 3 階には 2 段ベッドと子供用ベッ ドを設置し，4階ではキッチン・食卓・居間を持つ一般住居を模擬し た部屋を用意した. 5 階には自動販売機とシステムバスを設置した. このなかで，オフィス，居間，キッチンを取り上げ，実験前の室内 写真を図 19 に示す.
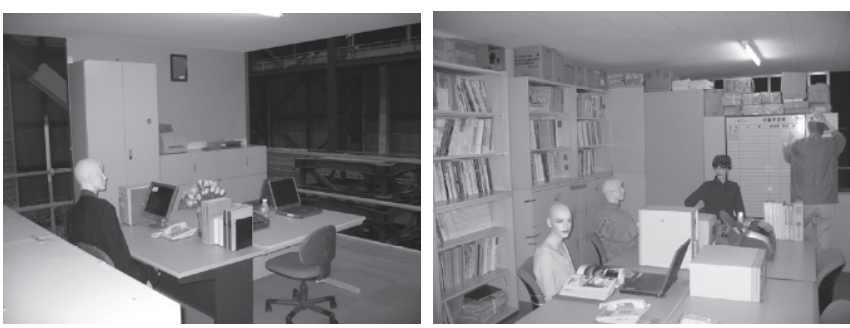

（a）オフィス（耐震対策あり）

（b）オフィス（耐震対策なし）

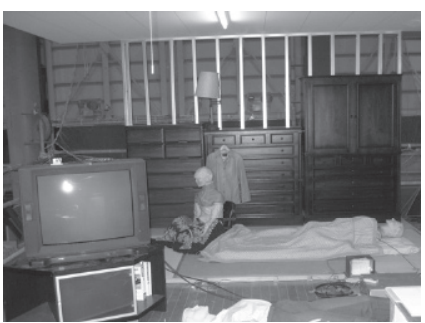

(c) 居間

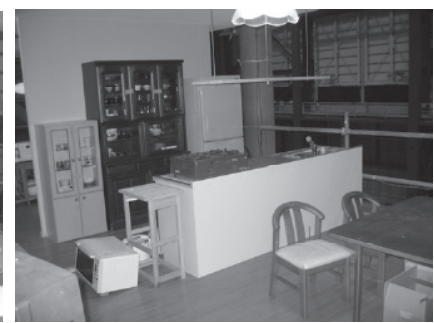

(d) キッチン
図 19 室内写真（実験前）

大振幅床応答において, 各室内は図 20 に示されるような被害を 受けた。このように，多くの家具の転倒，す心゙り移動，飛散等の被 害が見られるが，もしこれらの室内に実際に人がいた場合，家具什 
器によって受ける被害は, 命の危険に及ぶ可能性がある. 仮に居住 者に被害がなかったとしても, 地震時にこのような光景を目の当た りにしながら，200 秒以上も続くような摇れを経験する居住者は恐 怖におののき, 後の避難行動を大きく阻害することも推測される. 超高層建物内の地震時挙動をここまで鮮明, かつ総合的に再現した 実験の例はなく, このような記録は防災教育を行ううえで非常に貴 重な資料である ${ }^{10)}$.
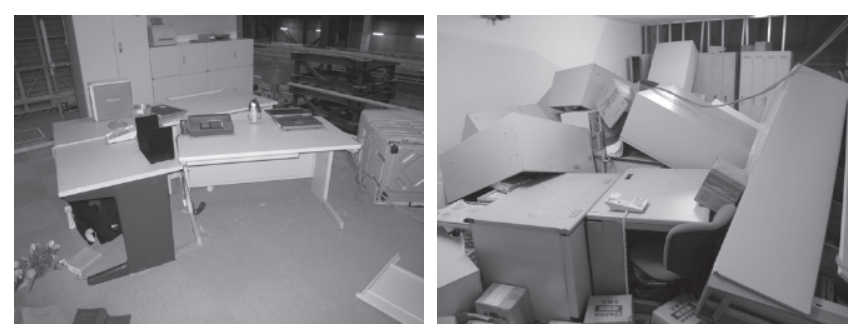

（a）オフィス（耐震対策あり）

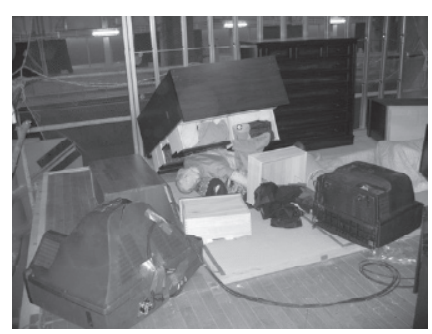

（b）オフィス（耐震対策なし）

(c) 居間

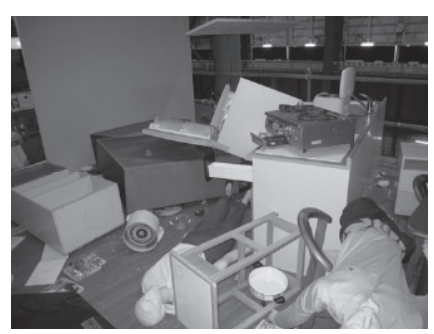

(d) キッチン

図 20 室内被害の様子（実験後）

\section{2 家具の転倒}

ここでは，オフィス階に焦点を当ててより詳細な考察を試みる. 1 部屋には転倒やすべり防止の耐震対策を施した机・ロッカー・本棚 を, もう 1 部屋には, 耐震対策を施していない机・ロッカー・本棚・ キャビネットを設置した。 また，このような大振幅応答を受ける室 内ではキャスター付コピー機が室内でどのように動き, 周辺にどの ような影響を与えるかを把握するために，両方の部屋にコピー機を 設置した。オフィス階では床材にはタイルカーペットを用い, 家具 を図 21 のように配置した。それら家具の諸元を表 11 に示す。

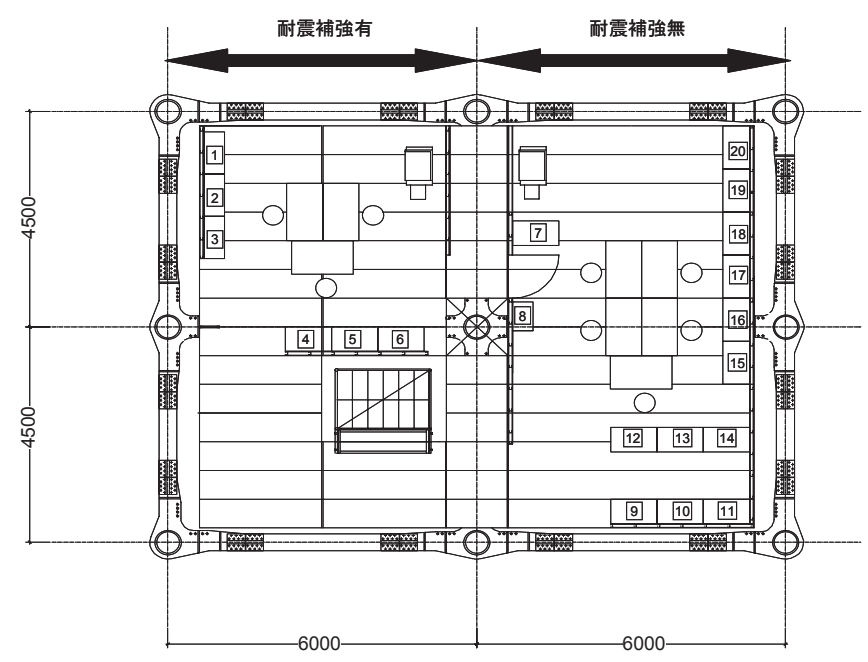

図 21 オフィス（試験体 2 階）
表 11 家具の諸元と転倒に関する実験結果

\begin{tabular}{|c|c|c|c|c|c|c|c|c|}
\hline & No. & 家具 & $\mathrm{W}(\mathrm{mm})$ & $\mathrm{D}(\mathrm{mm})$ & $\mathrm{H}(\mathrm{mm})$ & $\mathrm{Fb}(\mathrm{Hz})$ & $A_{0}\left(\mathrm{~m} / \mathrm{s}^{2}\right)$ & 転倒 \\
\hline 耐 & 1 & \multirow{2}{*}{ ロッカー(小） } & \multirow{2}{*}{900} & \multirow{2}{*}{515} & \multirow{2}{*}{1100} & \multirow{2}{*}{1.48} & \multirow{2}{*}{4.59} & \multirow{6}{*}{ NO } \\
\hline 震 & 2 & & & & & & & \\
\hline 補 & 3 & ロッカー（大） & 880 & 400 & 1790 & 1.16 & 2.19 & \\
\hline 強 & 4 & \multirow{3}{*}{ ロッカー(小) } & \multirow{3}{*}{900} & \multirow{3}{*}{515} & \multirow{3}{*}{1100} & \multirow{3}{*}{1.48} & \multirow{3}{*}{4.59} & \\
\hline あ & 5 & & & & & & & \\
\hline り & 6 & & & & & & & \\
\hline \multirow{13}{*}{$\begin{array}{l}\text { 耐 } \\
\text { 震 } \\
\text { 補 } \\
\text { 強 } \\
\text { な } \\
\text { し }\end{array}$} & 7 & \multirow{2}{*}{ ロッカー(大） } & \multirow{2}{*}{880} & \multirow{2}{*}{400} & \multirow{2}{*}{1790} & \multirow{2}{*}{1.16} & \multirow{2}{*}{2.19} & \multirow{2}{*}{ YES } \\
\hline & 8 & & & & & & & \\
\hline & 9 & \multirow{3}{*}{ キャビネット } & \multirow{3}{*}{900} & \multirow{3}{*}{515} & \multirow{3}{*}{1790} & \multirow{3}{*}{1.16} & \multirow{3}{*}{2.82} & \multirow{3}{*}{ NO } \\
\hline & 10 & & & & & & & \\
\hline & 11 & & & & & & & \\
\hline & 12 & 書庫(2段重ね) & 880 & 400 & 2200 & 0.61 & 1.78 & \\
\hline & 13 & 書庫 (大) & 600 & 400 & 1790 & 1.16 & 2.19 & \\
\hline & 14 & キャビネット & 900 & 515 & 1790 & 1.16 & 2.82 & \\
\hline & 15 & \multirow{3}{*}{ 書庫(2段重ね) } & \multirow{3}{*}{880} & \multirow{3}{*}{400} & \multirow{3}{*}{2200} & \multirow{3}{*}{0.61} & \multirow{3}{*}{1.78} & YES \\
\hline & 16 & & & & & & & \\
\hline & $\frac{17}{18}$ & & & & & & & \\
\hline & 19 & 書庫(小) & 880 & 400 & 1100 & 1.48 & 3.56 & NO \\
\hline & 20 & & & & & & & Tru \\
\hline
\end{tabular}

『非構造部材の耐震設計施工指針・同解説および而震設計施工要 領』(以降，指針）3）によって推定される家具の短辺方向の転倒限界 加速度 $A_{0}$ を表 11 に示寸. 家具の転倒は床応答の最大加速度と最大 速度に影響を受け，両者が家具の転倒限界值を超えた場合に転倒が 生じる. 床応答の振動数 $F_{\mathrm{e}}$ が家具の形状から決まる境界振動数 $F_{\mathrm{b}}$ より小さい場合は, 転倒に関する判定は床応答の最大加速度に支配 される. 長周期で摇れる超高層建物の床応答は, この領域に入りや すく, 床応答速度が転倒限界值を超えた後に, 床応答加速度が転倒 限界加速度に到達寸る. 本実験においても床応答の振動数 $\left(F_{\mathrm{e}}=0.3\right.$ $\mathrm{Hz})$ は, オフィス階に配置したす心゙ての家具の境界振動数 $F_{\mathrm{b}}$ よりも 小さく, 転倒の検討においては, 床応答の最大加速度 (表 10) と個々 の家具の転倒限界加速度 $A_{0}$ を比較することになる. 耐震対策が施さ れている家具の転倒限界加速度は，対策されていない場合の転倒限 界加速度であり，2段重ねにされた書庫の転倒限界加速度は既往の 研究 11) を参考に算出した.

表 11 には実験によって家具に転倒が生じたかを合わせて示して いる（NO：転倒しなかった，YES：転倒した）。再現された応答の $\mathrm{Y}$ 方向の最大加速度は $4.31 \mathrm{~m} / \mathrm{s}^{2}, \mathrm{X}$ 方向の最大加速度は $2.92 \mathrm{~m} / \mathrm{s}^{2}$ である. 表 11 から, 耐震対策のあるすべての家具は転倒しなかっ たことが確認できる。而震対策が施されていない家具については 9 個が転倒し，残りの 5 個が転倒を免れた。配置された家具の転倒限 界加速度と実際に再現された応答加速度を照らしあわせると, 表 11 の No9 11, No19, No20 は, 床応答加速度が指針による転倒限界 加速度 $A_{0}$ を上まわっているが，実際には転倒していない，No9 11 が転倒しなかったのは，それ以前に転倒した家具によって支えられ たからであり，他の転倒した家具によって支えられていなければ， No9 11 は転倒した可能性が高い，一方，No19 と No20 は，ビデオ による検証から, 床応答加速度が $3 \mathrm{~m} / \mathrm{s}^{2}$ を越えたあたりからすべり 始めたことを確認した．No19 と No20 は，このす心゙りによって転 倒モーメントが減少し, 転倒を免れたといえる. 床応答加速度が 3 $\mathrm{m} / \mathrm{s}^{2}$ 程度からすべりを生じたことに着目すれば，No19 と No20の タイルカーペットに対する静止摩擦係数はおよそ 0.3 となり，指針 によって想定されている金属とじゅうたんによる静止摩擦係数 0.2 0.5 と整合する. No19 と No20の転倒限界加速度は, 他の家具 に比べて值が大きく, すべり時加速度を上回る．耐震対策のない居 
室における個々の家具の挙動は, 指針による転倒限界加速度とす心゙ り時加速度に対応する摩擦係数を参照することによっておおよそ評 価できる.

\section{3 コピー機の挙動}

長周期地震動を受ける超高層建物の最上層の床応答が再現された 室内において, コピー機（図 22）の動きが最も衝撃的であった.才 フィス階にある約 $100 \mathrm{~kg}$ のコピー機はおよそ $2.5 \mathrm{~m} / \mathrm{s}$ で室内を動き 回り，室内の間仕切壁 (LGS) に大きな穴を開けた。この実験時のコ ピー機の軌跡を図 23 に示寸.コピー機が動き回ることによって, コピー機が周辺のデスクや椅子などを倒す光景が見られた(図 20 a).このような場合に, 人が地震時にデスク下に避難したとしても, コピー機による衝撃によって被害を受ける可能性がある. 実験時の コピー機は周辺の壁やデスクに衝突し, 最終的に転倒した。ここで は, コピー機の周辺に何もない状態を仮定し, 転倒しない場合のコ ピー機の挙動を解析によって検討してみる. この実験ではコピー機 が床加速度 $1 \mathrm{~m} / \mathrm{s}^{2}$ で動き出したので, キャスターのストッパーが効 いていないコピー機の静止摩擦係数 $\mu$ を 0.1 とする. コピー機の解 析では $100 \mathrm{~kg}$ の質量を持つ 1 自由度系モデルを用い, 初期剛性を $100 \mathrm{kN} / \mathrm{m}$ に設定した完全弾塑性の履歴を与える. 解析用入力波と しては, 実験で再現された長周期地震動を受ける超高層建物の床応 答に加え, エルセントロ波（レベル 2 : 最大速度を $0.5 \mathrm{~m} / \mathrm{s}$ に基準化） を受ける低層建物の床応答を採用寸る. エルセントロ波による床応 答は固有周期 0.5 秒の 1 自由度弹性解析 $(\mathrm{h}=0.02)$ によって得られた もので, 最大床応答加速度 $13 \mathrm{~m} / \mathrm{s}^{2}$ ・速度 $1.1 \mathrm{~m} / \mathrm{s}$ は, それぞれ超高 層建物の最大床応答值と比べると加速度で約 3 倍, 速度で約半分と なる。

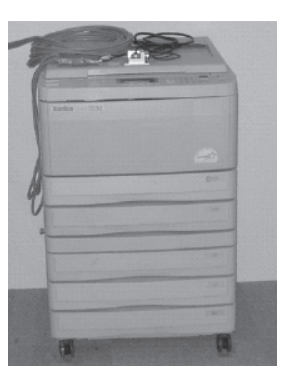

図 22 コピー機

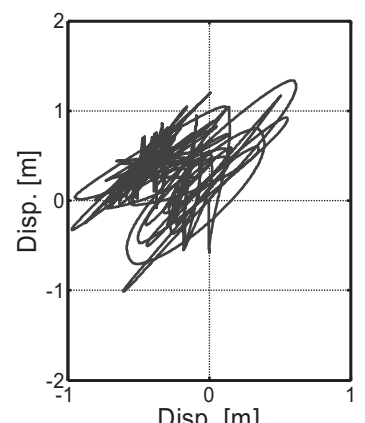

（1）長周期地震動を受ける 超高層建物内

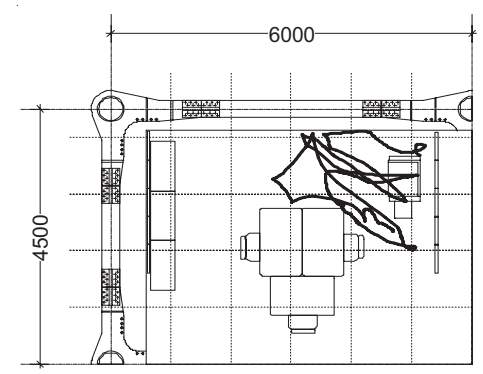

図 23 実験によるコピー機の軌跡

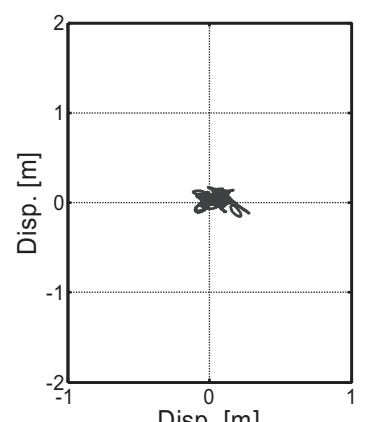

Disp. [m]

(2) エルセントロ波を受ける 低層建物内
図 24 解析による各種建物内のコピー機の軌跡
解析から得られたコピー機の軌跡を図 24 に示寸. 超高層建物の 床応答を受けるコピー機の最大速度と最大変位は $2.45 \mathrm{~m} / \mathrm{s}$ と 1.46 $\mathrm{m}$ に，また累積変位は $116.6 \mathrm{~m}$ に達した，一方，エルセントロ波を 受ける低層建物のコピー機の最大速度と最大変位は $1.60 \mathrm{~m} / \mathrm{s}$ と $0.30 \mathrm{~m}$ になり, 累積変位は $14.3 \mathrm{~m}$ となる. 超高層建物の床応答を 受けるコピー機の最大速度はエルセントロ波を受ける低層建物の場 合の 1.5 倍であるが，累積変位は 8.1 倍にもなる．このように，長 周期地震動を受ける超高層建物内のコピー機の挙動は, 長時間, 広 範囲に動き回ることによって特徴づけられる.

一方，コピー機のキャスターにはストッパーが付いていることが 多く, そのストッパーを効くようにするだけで摩擦係数は 0.4 程度 まで上昇する ${ }^{12)}$. 摩擦係数 $\mu$ を 0.4 にして同様の解析を行うと, 超 高層建物の床応答を受けるコピー機の最大速度, 変位は $0.05 \mathrm{~m} / \mathrm{s}$, $0.01 \mathrm{~m}$ に, 累積変位は $5.5 \mathrm{~m}$ となり, ストッパーを効かせることに より, 最大変位は約 $1 \%$ に, 累積変位は約 $5 \%$ にまで減少する. 超高 層建物内では, コピー機の挙動に対寸るストッパーの影響が大きく, 大振幅床応答によってもたらされるコピー機による被害は, ストッ パーを使用することによって激減する.

\section{9. まとめ}

本研究では震動台実験によって超高層建物の応答を再現するため に, 震動台が固有に抱える制約条件を克服し得るシステムを考えた. 径 $1.0 \mathrm{~m}$ の積層ゴム支承 4 基で支える層を, 極厚コンクリートスラ ブ錘を介して 2 段重㸚とする増幅システムの上に，床応答の再現す る鋼構造架構を配し, 積層ゴム支承単体の変形性能の 2 倍の増幅性 能を意図した。

構築した実験システムに対する入力波の作成においては，現時点 で考えうる 3 種類の手法を取り上げ，その特徴と実現性を総合的に 比較検討した，振幅を単純にスケールする基準化東遊園地 2 によっ て再現される最大加速度・最大変位は目標值に達するが, 長時間の大 振幅応答を忠実に再現できない。目標応答をそのまま逆解析する補 償入力波 $\mathrm{A} 1$ は，再現性の良い入力波を同定できるが，震動台自身 の累積変位を抑えることができず，限界油量を超えてしまう。必要 油量が限界油量以内に収まるようにした補償入力波 $\mathrm{A} 2$ では, 再現 される応答が最大加速度・最大変位は目標最大值の半分にしか達し ない. これらを踏まえて, 試験体の 1 次振動数 $f_{1}$ と同じ振動数を持 った正弦波を目標応答の骨格曲線に即し時刻歴で係数倍する人工目 標応答を作成し, 人工目標応答を逆解析することによって補償入力 波 B1 を作成した。これにより, 実験システムの増幅特性を最大限 に活かし, 長周期地震動による超高層建物の長時間続く大振幅床応 答を実現し，その必要油量を極めて効率的に減少させることができ た.

実験においては, 解析モデルの不確定性を踏まえ, 補償入力波 B1 による予備実験結果に基づいて, さらに補償入力波 $\mathrm{B} 1$ の振幅を調 整し, 所定の目標振幅を長時間にわたって実現する補償入力波 B2 を作成した。これにより, 室内の危険性につながる家具什器の挙動 を実規模空間において総合的に記録することができた，再現された 家具什器の転倒に関する検討を行い, 而震対策された家具什器が室 内空間の安全性確保に大きく貢献することを示した。長周期地震動 を受ける超高層建物内のコピー機の長時間, 広範囲にわたって衝突 
を繰り返す挙動についても考察し, ストッパーの有効性に言及した. こうした超高層建物の室内の忠実な再現映像は人々の防災意識を向 上させる有効な資料となる.

本研究で構築した実験システムは, 繰り返し使用することができ る. その実験システム上で目標応答を合理的に再現するための手法 について提案した。 今後, 本実験システムと手法を応用して, 室内 安全性に関する研究を継投的に行っていく予定である.

\section{謝辞}

本研究の推進にあたって,「E-ディフェンスを活用した減災対策 推進委員会 (委員長 : 岡田恒男 東京大学名誉教授)」の委員各位か ら貴重なご助言をいただきました。ここに記して感謝の意を表しま す.

\section{参考文献}

1）(社)土木学会, (社) 日本建築学会: 海溝型巨大地震による長周期地震動と 土木·建築構造物の耐震性向上に関する共同提言, 2006. 11.

2）長江拓也, 梶原浩一, 藤谷秀雄, 福山國夫, 川辺秀憲, 大西一嘉, 城戸 史郎, 中島正愛: 家具および非構造部材に着目する高層建物の地震応答 再現実験 E-ディフェンス振動台による実規模実験システム, 日本建築 学会構造系論文集，No.628，pp1007-1014，2008.6.

3）非構造部材の耐震設計施工指針・同解説および而震設計施工要領, 日本 建築学会, 2003.

4）長江拓也, 福山國夫, 藤谷秀雄, 梶原浩一, 中島正愛 : 30 階建物の床応 答と応答変形に関する時刻歴地震応答解析 高層建物の非構造部材·家 具什器に関する E-ディフェンス振動実験 その 3 , 日本建築学会大会学 術講演梗概集，B-2，pp.555-556，2007.
5）藤谷秀雄, 川辺秀憲, 長江拓也, 福山國夫, 梶原浩一, 中島正愛, 城戸 史郎 : 想定南海地震時の神戸市東遊園地における強震動予測と既往観測 記録との比較 高層建物の非構造部材·家具什器に関する E-ディフェン 又振動実験 その 2 , 日本建築学会大会学術講演梗概集, B-2, pp.553-554, 2007.

6）山田哲，前澤将男，森利弘，島田侑子，佐藤英児，秋山宏：エネルギー 入力に着目した実大震動台破壊実験施設性能確認試験の評価, 日本建築 学会構造系論文集, No.612, pp.207-214, 2007.2.

7）梶原浩一, 佐藤栄児, 田川泰敬 : 実大三次元震動破壊実験装置（E-ディ フェンス）の加振性能と活用について, 運動と振動の制御シンポジウム 講演論文集，No.9，pp.313-316， 2005.

8）梶原浩一, 長江拓也, 福山國夫, 藤谷秀雄, 中島正愛 : E-ディフェンス 振動実験における 30 回床応答再現のための加振入力と実験結果 高層 建物の非構造部材・家具什器に関する E-ディフェンス振動実験 - その 5 , 日本建築学会大会学術講演梗概集，B-2，pp.559-560， 2007.

9) 田川康敬, 福井和良, 低感度補償器を用いた非線形モデルの逆ダイナミ ックスの計算, D\&D1994 講演論文集, pp.B185-B188, 1994.

10）独立行政法人防災科学技術研究所 兵庫耐震工学研究センター, 加震実 験映像, http://www.bosai.go.jp/hyogo/movie.html，（参照 2008-05-31）

11）金子美香，林康裕：剛体の転倒限界に関する基礎的検討，日本建築学会 構造系論文集，No.479， pp.41-49， 1996,1.

12）正月俊行, 翠川三郎, 大堀道広, 三浦弘之：超高層建物におけるオフィ ス内の家具群の地震時シュミュレーション, 日本建築学会構造系論文集, No.620, pp43-49, 2007.10.

(2008年 6 月 9 日原稿受理，2008年11月19日採用決定） 